\title{
組織プラスミノゲンアクチベータによる血栓溶解過程 に及ぼすアルガトロバン及び未分画ヘパリンの影響
}

\begin{tabular}{|c|c|c|}
\hline 山田恵三 & 肇 & 高田 \\
\hline 米田 充 & 増田治史 & 中川 \\
\hline $\begin{array}{l}\text { 山田結佳 } \\
\text { 澤田昌平 }\end{array}$ & $\begin{array}{l}\text { 玉 垣俊 幸 } \\
\text { 中川 雅夫 }\end{array}$ & 山上正仁 \\
\hline
\end{tabular}

\section{Effects of Argatroban and Unfractionated Heparin on t-PA Induced Thrombolysis}

\author{
Keizo YAMADA, Hajime TSUJI, Osamu TAKADA, \\ Mitsuru YONEDA, Haruchika MASUDA, Katsumi NAKAGAWA, \\ Yuka YAMADA, Toshiyuki TAMAGAGI, Masahito YAMAGAMI, \\ Shohei SAWADA and Masao NAKAGAWA
}

Key words : thrombolysis, thrombosis model, argatroban, heparin, t-PA,

The effects of argatroban (a selective thrombin inhibitor) and unfractionated heparin (UFH) on t-PA induced thrombolysis were compared in an experimental thrombosis using the microvasculature of hamster cheek pouch. The thrombus was produced by irradiation of ultraviolet light (intensity ; $20 \mathrm{~mW} / \mathrm{mm}^{2}$, wave length ; 400-500 $\mathrm{nm}$ ) in combination with the intravascular administration of fluorescein sodium $(50 \mathrm{mg} / \mathrm{kg})$, until the development of thrombus stenosed $99 \%$ of the luminal area of the venule $(50-70 \mu \mathrm{m})$. Thrombolytic process mediated by $\mathrm{t}-\mathrm{PA}$ was observed on a color television through a high gain video camera and recorded on videotape. The effects of these anticoagulants administered with $\mathrm{t}$-PA were evaluated by the percent stenosis of lumen and the percent area of thrombus, which were calculated by the computed video analyzer. Prothrombin time (PT) and activated partial thromboplastin time (aPTT) were measured on plasma samples obtained one hour after the injection of anticoagulants. Bleeding time was measured on the shaved left medial hind leg with blade before sampling the blood. Argatroban $(0.1-0.3 \mathrm{mg} / \mathrm{kg} \cdot \mathrm{hr})$ significantly enhanced thrombolysis by t-PA $\left(72 \times 10^{4} \mathrm{IU} / \mathrm{kg} \cdot \mathrm{hr}\right)$ in one and two hours after infusion of t-PA. Argatroban $(0.1-0.3 \mathrm{mg} / \mathrm{kg} \cdot \mathrm{hr})$ prolonged PT, aPTT and bleeding time dose dependently and significantly at the dose of $0.3 \mathrm{mg} / \mathrm{kg} \cdot \mathrm{hr}$. Argatroban $(0.3 \mathrm{mg} /$ $\mathrm{kg} \cdot \mathrm{hr})$ enhanced thrombolysis by t-PA $\left(72 \times 10^{4} \mathrm{IU} / \mathrm{kg} \cdot \mathrm{hr}\right)$, but UFH $(12.5$ anti-X U/ $\mathrm{kg} \cdot \mathrm{hr})$ delayed it. Argatroban $(0.3 \mathrm{mg} / \mathrm{kg} \cdot \mathrm{hr})$ did not significantly prolonged PT and 
aPTT as compared with UFH $(12.5$ anti-X U/kg $\cdot \mathrm{hr})$. From these results, argatroban was suggested to be a useful additional anticoagulant in thrombolytic therapy using t-PA.

\section{緒 言}

血栓溶解療法においては，血栓溶解に伴い血 栓表面に出現するトロンビンの作用を阻害する ことにより新たな血栓形成が抑制され，速やか な血管の再疎通が期待できると考えられる。従 来，組織プラスミノゲンアクチベータ (t-PA) による血栓溶解療法において未分画へパリン (UFH) を始めとする種々の抗凝固薬が併用さ れているが，これらの血栓溶解過程に及ぼす影 響に関しての知見はそしいのが現状である。今 回，筆者らはハムスターの煩袋の微小血管を用 いて作製した血栓を対象として，アルガトロバ ンおよび UFH の t-PA による血栓溶解過程に 及ぼす影響を検討したので報告する。

\section{対象および方法}

1）微小血管内血栓モデル :

雄性ハムスター（体重 : 120-150 g）を用い, ペントバルビタール $(100 \mathrm{mg} / \mathrm{kg}$; i. p.) 麻酔下 に気管内挿管後，右鎖骨下動脈および右大腿静 脈にカニュレーションを行い, Shanberge ら の方法に従いハムスターの右煩袋を観察台上に 展開，上層を切開し結合織を除去して下層の微 小血管床を露出した。 ハムスターの煩袋は $37^{\circ} \mathrm{C}$ の Bicarbonate buffer にて $1 \mathrm{ml} / \mathrm{min}$ の速度 で灌流し，血管床は蛍光倒立顕微鏡（オリンパ ス社製）に接続した高感度テレビカメラ (Flovel 社)を通してモニター上にて観察した。 微小血管内血栓は，fluorescein sodium（50 $\mathrm{mg} / \mathrm{kg}$ ）を右鎖骨下動脈より注入，5分後に水

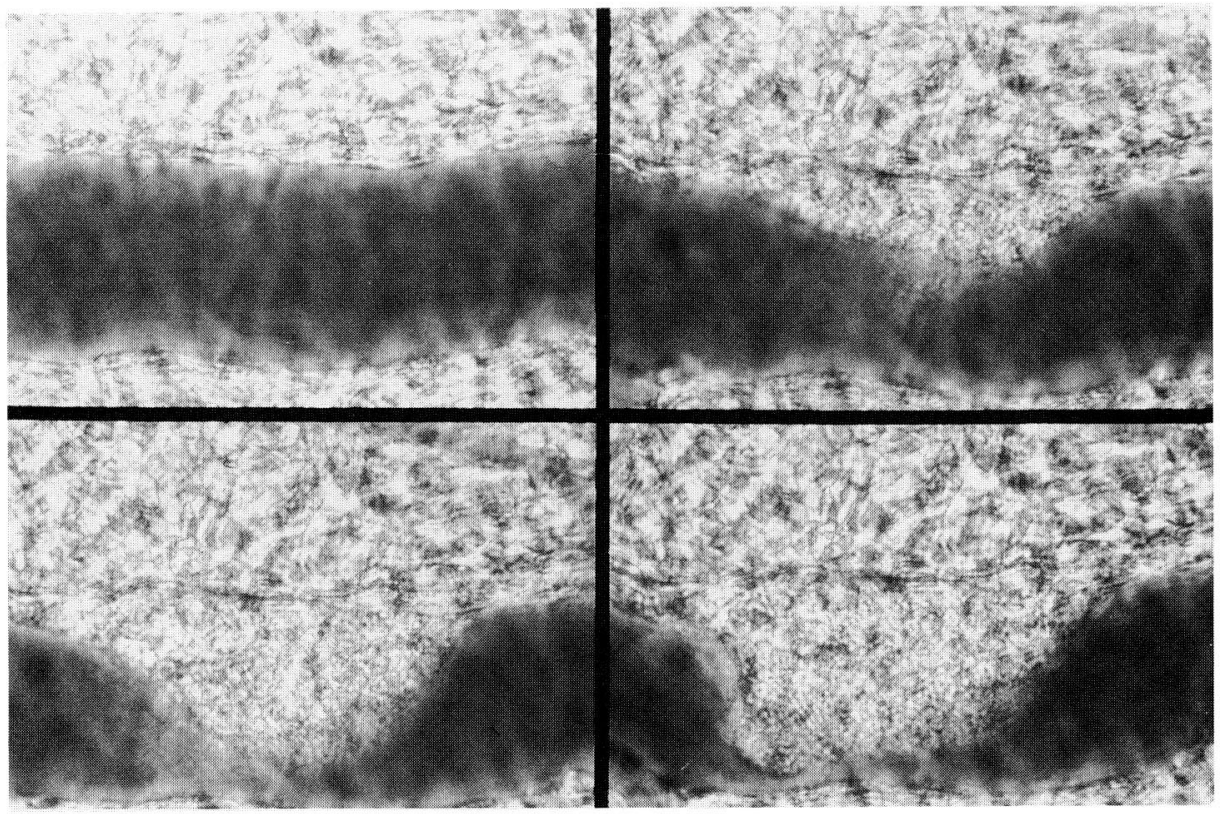

Fig. 1 Thrombus was formed in the venule (diameter : $70 \mu \mathrm{m}$ ) of hamster cheek pouch using filtered light from mercury lamp, 5 minutes after injection of fluorescein sodium. Each panels represents the time course of thrombus formation just after (upper left), 2 minutes (upper right), and 4 minutes (lower left) after the starting of irradiation. Lower right panel shows the accomplished thrombus just after the discontinuation of filtered light. 


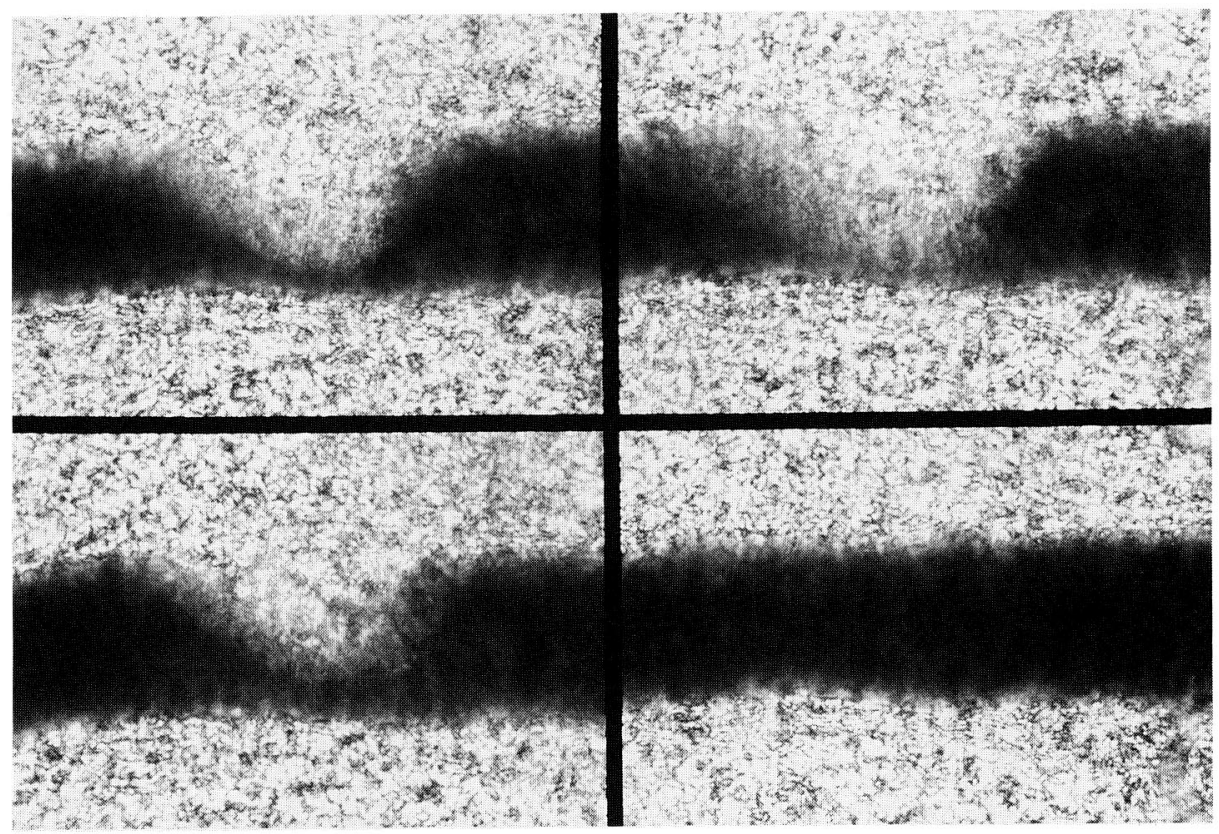

Fig. 2 The infusion of t-PA $\left(72 \times 10^{4} \mathrm{IU} / \mathrm{kg} \cdot \mathrm{hr}\right)$ was started 15 minutes after the discontinuation of irradiation and continued for 4 hours. Thrombolytic process mediated by $\mathrm{t}$-PA $\left(72 \times 10^{4} \mathrm{IU} / \mathrm{kg} \cdot \mathrm{hr}\right)$ before (upper left), 1 hour (upper right), 2 hours (lower left), and 4 hours (lower right) after the infusion.

銀ランプを光源とし, FITC フィルターを通し た励起光（強度 $20 \mathrm{~mW} / \mathrm{mm}^{2}$, 波長 $400 \sim 500$ $\mathrm{nm}$ ) の励起光を対象血管 (細静脈, 直径 ; $50 \sim 70$ $\mu \mathrm{m})$ の半側に照射して作製した. 励起光照射面 積は $2,000 \sim 2,500 \mu \mathrm{m}^{2}$ に調節し血栓による血 管閉塞率が $99 \%$ になった時点で照射を終了 し，偏在性血栓を作製した（図 1). 励起光照射 終了 15 分後, t-PA（TD-2061; 東洋紡績社）を 右鎖骨下動脈より, $72 \times 10^{4} \mathrm{IU} / \mathrm{kg} ・ \mathrm{hr}$ の濃度 で 4 時間持続注入した。血栓溶解過程 (図 2) は テレビカメラに接続したVTRにより記録，画 像解析装置 (XL 500 ; Avionics 社) を用いて, 再生画像を解析した. すなわち, t-PA 注入直前 の血管径を $\mathrm{D}_{0}$, 血栓面積を $\mathrm{A}_{0}$ とし, これに対 する 1 時間毎の血栓の高さ $\mathrm{H}_{1-4}$ 並びに血栓面 積 $\mathrm{A}_{1-4}$ より，\%血管閉塞率，\%血栓面積を算 出し, 血栓溶解過程の指標とした (図 3).

\section{2） t-PA による血栓溶解過程に及ぼす各種} 抗凝固剂の影響 :

生食をコントロールとし, 選択的抗トロンビ ン剤アルガトロバン（MD 805, 三菱化成工業： $0.05,0.1,0.2,0.3 \mathrm{mg} / \mathrm{kg} \cdot \mathrm{hr})$ および $\mathrm{UFH}$

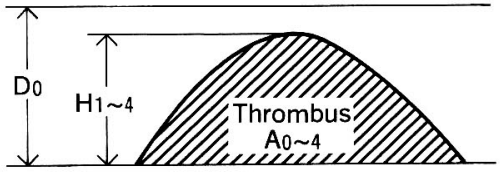

$\%$ Area of thrombus $1 \sim 4=\frac{A_{1} \sim 4}{A_{0}} \times 100$

$\%$ Stenosis $1 \sim 4 \quad=\frac{\mathrm{H}_{1} \sim 4}{\mathrm{D}_{0}} \times 100$

Fig. 3 The assessment of the thrombolytic process. Percent area of thrombus was calculated as the ratio between the area of thrombus at every one hours after $\mathrm{t}-\mathrm{PA}$ infusion $\left(\mathrm{A}_{1-4}\right)$ and the original area $\left(A_{0}\right)$. Percent stenosis of the lumen by thrombus was calculated as the ratio between the height of thrombus at every one hours $\left(\mathrm{H}_{1-4}\right)$ and the original vessel diameter $\left(\mathrm{D}_{0}\right)$.

(Kabi : 12.5 anti- $\mathrm{X}_{\mathrm{a}} \mathrm{U} / \mathrm{kg} \cdot \mathrm{hr}$ ) を右大腿静脈 より $\mathrm{t}-\mathrm{PA}$ とともに併用投与し血栓溶解過程に 及ほす影響を比較検討した。

\section{3) 凝血学的検討 :}

生食をコントロールとし右鎖骨下動脈より投 与するとともにアルガトロバン $(0.1,0.2,0.3$ 

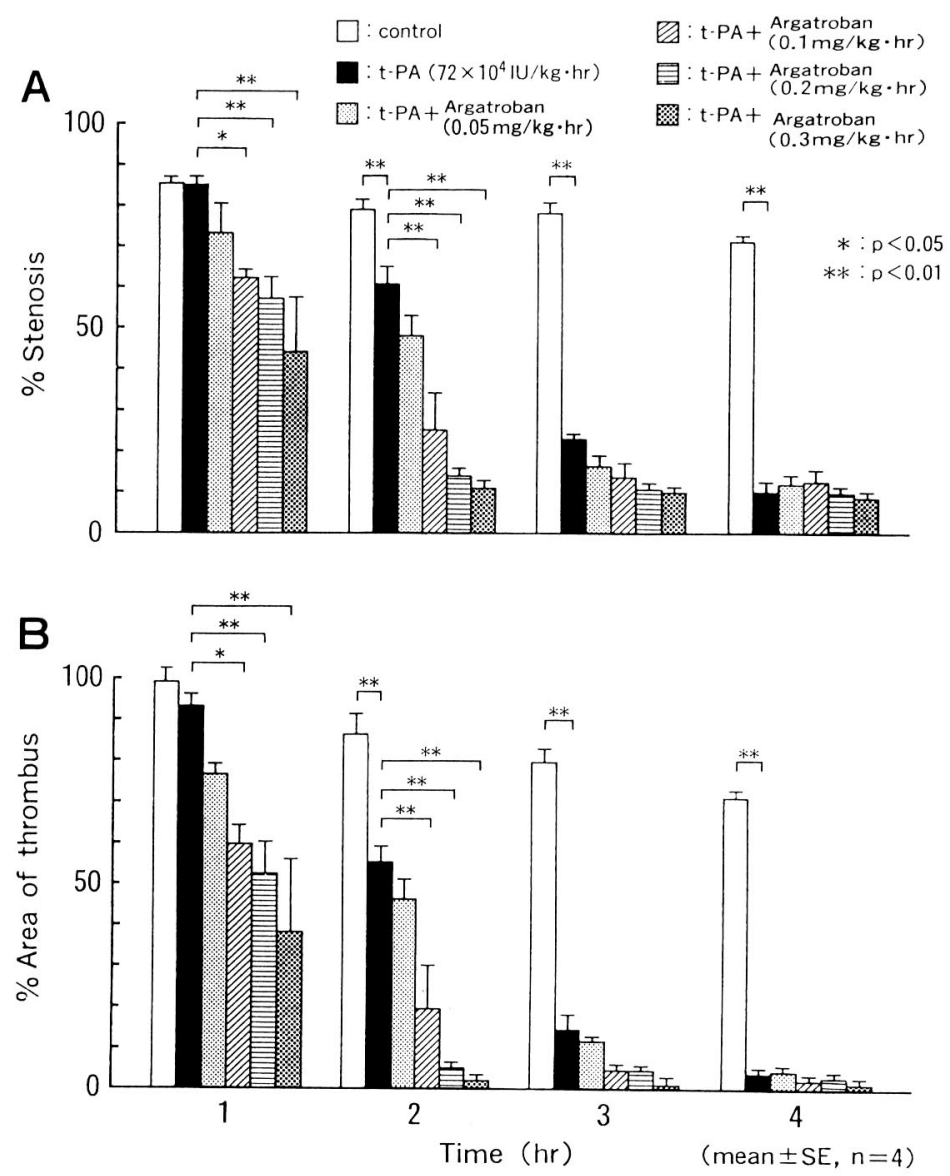

Fig. 4 Effect of argatroban on t-PA induced thrombolysis. Argatroban $(0.1-0.3 \mathrm{mg} / \mathrm{kg} \cdot \mathrm{hr})$ in combination with $\mathrm{t}-\mathrm{PA}$ significantly accelerated the decrease of percent stenosis (A) and percent area of thrombus (B) dose dependently as. compared with control. Values were expressed as mean $\pm \mathrm{SE}$.

$\mathrm{mg} / \mathrm{kg} \cdot \mathrm{hr})$ および UFH $\left(12.5\right.$ anti- $\mathrm{X}_{\mathrm{a}} \mathrm{U} / \mathrm{kg}$ ・ hr）を右大腿静脈より 1 時間持続投与しクエン 酸加血漿を得, プロトロンビン時間 (PT) およ び活性化部分トロボプラスチン時間 (aPTT) を測定した.アルガトロバンに扔いては出血時 間も採血前に測定した，PT 抢よび aPTT はそ れぞれリオプラスチン 1 号(持田製薬)，プラテ リン・プラス・アクチベータ（オルガノテクニ カ社）を用いて測定した。出血時間は右足伸側 を剪刀にて約 $1 \mathrm{~mm}$ 切傷し, 止血に要する時間 を測定した。

\section{統計学的検討：}

一元配置分散分析（ANOVA）法により行っ
た。測定値は平均値士標準誤差として表した。

\section{結＼cjkstart果}

\section{1） t-PA による血栓溶解過程に及ぼすアル ガトロバンの影響}

\section{A. \% 血管閉塞率（図 4A）:}

コントロール群における微小血管内血栓は, 血管閉塞率において 4 時間後, $71.5 \pm 1.0 \%$ ま で減じ, 自然溶解を認めた。

一方, t-PA 単独投与群では 2 時間以降におい てコントロール群に比し有意の血栓溶解を認め た.しかし，t-PA 単独投与による血栓溶解にお ける形態的変化は極めて複雑であり血栓の溶解 
とともに血栓表面で新たな血栓形成が 1 時間後 まで進行し途絶と再疎通を繰り返した。以後, 血管閉塞率が減少するに従い，再途絶は認めら れなくなり 2 時間後よりコントロール群に比し 有意な血栓溶解が認められた。アルガトロバン $(0.05 \sim 0.3 \mathrm{mg} / \mathrm{kg} \cdot \mathrm{hr})$ は投与量依存性に tPA による血栓溶解を促進した.アルガトロバ ン（0.1 0.3 mg $/ \mathrm{kg} ・ \mathrm{hr} ）$ の併用群においては t-PA 単独投与群に比し, $1 \sim 2$ 時間後に有意の 血栓溶解の促進を認めたが, $0.05 \mathrm{mg} / \mathrm{kg} \cdot \mathrm{hr}$ の 併用では有意差は認めなかった。また，アルガ トロバン $0.1 \mathrm{mg} / \mathrm{kg} \cdot \mathrm{hr}$ 以上の併用各群間には 有意差を認めなかった。アルガトロバン併用時 の血栓形態の経時的変化においては t-PA 単独 投与群において観察された血栓表面上での新た な血栓形成が本剤の併用により抑制され，これ は $0.1 \sim 0.3 \mathrm{mg} / \mathrm{kg} ・ \mathrm{hr}$ の併用群に顕著に認め られた。

B. \% 血栓面積 (図 4 B) :

コントロール群において 4 時間後の血栓面積 は $71.3 \pm 1.7 \%$ であり自然溶解を認めた. t-PA 単独投与群では 2 時間以降においてコントロー ル群に比し有意の血栓面積の減少を認めた。ア ルガトロバン併用時の血栓面積の経時的減少は 血管閉塞率と近似した変化を示した。

2) 凝血学的検討 :

A. アルガトロバンの PT, aPTT および出 血時間に及ぼす影響

(1) $\mathrm{PT}$ (図 $5 \mathrm{~A}$ ):

アルガトロバンはコントロール群 $(10.8 \pm 0.5$ $\mathrm{sec})$ に比し $0.1 \mathrm{mg} / \mathrm{kg} \cdot \mathrm{hr}(10.3 \pm 0.6 \mathrm{sec})$ お よび $0.2 \mathrm{mg} / \mathrm{kg} ・ \mathrm{hr}(11.2 \pm 0.4 \mathrm{sec})$ の投与で は有意差は認めなかったが, $0.3 \mathrm{mg} / \mathrm{kg} ・ \mathrm{hr}$ $(12.8 \pm 1.0 \mathrm{sec})$ の投与にてコントロール群に 比し有意な延長を認めた。

(2) $\operatorname{aPTT}($ 図 5 B) :

$\mathrm{PT}$ と同様にアルガトロバンはコントロール 群 $(28.8 \pm 0.4 \mathrm{sec})$ に比し $0.1 \mathrm{mg} / \mathrm{kg} \cdot \mathrm{hr}$ $(30.7 \pm 0.8 \mathrm{sec})$ および $0.2 \mathrm{mg} / \mathrm{kg} \cdot \mathrm{hr}(31.6 \pm$

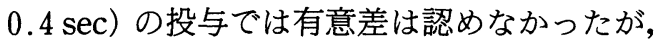
$0.3 \mathrm{mg} / \mathrm{kg} \cdot \mathrm{hr}(34.6 \pm 2.1 \mathrm{sec})$ の投与にてコ ントロール群に比し有意な延長を認めた。

(3) 出血時間 (図 6):
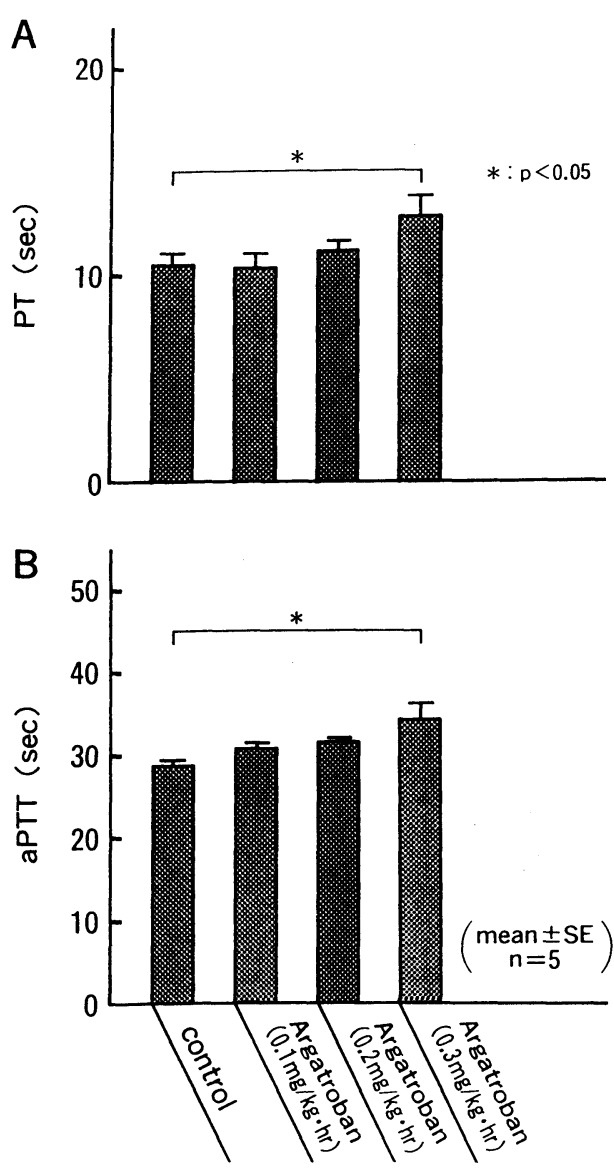

Fig. 5 Effect of argatroban on PT and aPTT. Argatroban prolonged PT (A) and PTT (B) dose dependently and significantly at the dose of $0.3 \mathrm{mg} /$ $\mathrm{kg} \cdot \mathrm{hr}$. Values were expressed as mean $\pm \mathrm{SE}$.

アルガトロバンはコントロール群 $(204 \pm 6$ $\mathrm{sec})$ に比し $0.1 \mathrm{mg} / \mathrm{kg} ・ \mathrm{hr}(228 \pm 12 \mathrm{sec})$ およ び $0.2 \mathrm{mg} / \mathrm{kg} ・ \mathrm{hr}(228 \pm 12 \mathrm{sec})$ の投与では有 意差は認めなかったが, $0.3 \mathrm{mg} / \mathrm{kg} ・ \mathrm{hr}(265 \pm$ $9 \mathrm{sec})$ の投与にてコントロール群に比し有意な 延長を認めた.t-PA との併用時も同様の傾向を 示すが, アルガトロバン単独投与群に比し, 有 意な延長は認めなかった。

B. アルガトロバンと UFH の PT, aPTT に及ぼす影響についての比較検討

(1) PT (図 $7 \mathbf{A}$ ):

$\mathrm{PT}$ はコントロール群 $(10.8 \pm 0.5 \mathrm{sec})$ に比 し, アルガトロバン $0.3 \mathrm{mg} / \mathrm{kg} ・ \mathrm{hr}(12.8 \pm 1.0$ 


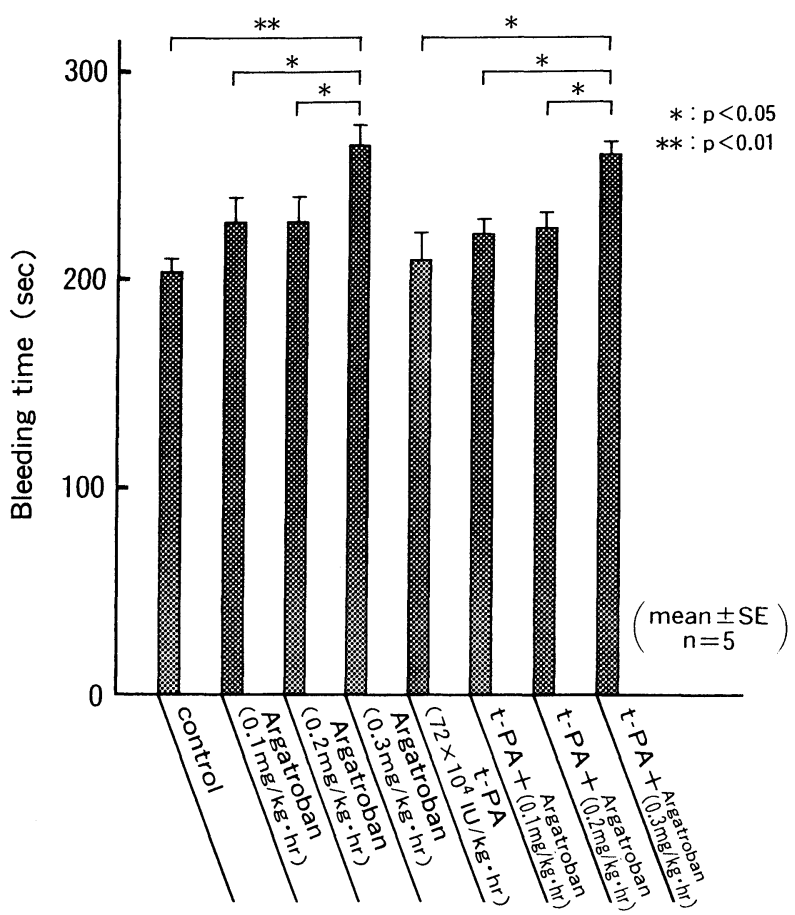

Fig. 6 Effect of argatroban on bleeding time. Argatroban $(0.1-0.3 \mathrm{mg} / \mathrm{kg} \cdot \mathrm{hr})$ prolonged bleeding time dose dependently and significantly at the dose of $0.3 \mathrm{mg} / \mathrm{kg} \cdot \mathrm{hr}$. Argatroban with t-PA prolonged bleeding time as much as argatroban alone. Values were expressed as mean $\pm \mathrm{SE}$.

sec）の投与では有意な延長を認めた. UFH 群 $(12.4 \pm 0.4 \mathrm{sec})$ ではコントロール群に比し延 長傾向を認めるも有意差は認めなかった。

(2) $\operatorname{aPTT}($ 図 $7 \mathbf{B})$ :

aPTT はコントロール群 $(28.8 \pm 0.4 \mathrm{sec})$ に 比し, アルガトロバン $0.3 \mathrm{mg} / \mathrm{kg} ・ \mathrm{hr}(34.6 \pm$ $2.1 \mathrm{sec})$ の投与では有意な延長を認めた. UFH

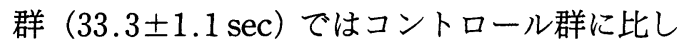
延長傾向を認めるも有意差は認めなかった。

3） アルガトロバンおよび UFH のt-PA に よる血栓溶解過程に及ぼす影響についての 比較検討

\section{A. \% 血管閉塞率 (図 $8 \mathrm{~A}$ ) :}

t-PA 単独投与群に比し, 投与開始後 $1 \sim 2$ 時 間においてアルガトロバン $(0.3 \mathrm{mg} / \mathrm{kg} \cdot \mathrm{hr})$ で \% 血管閉塞率の有意の減少を認め, UFH 群 では 2 時間以降において遅延する傾向を認め た.また UFH 群における血栓溶解過程では, アルガトロバン $(0.3 \mathrm{mg} / \mathrm{kg} \cdot \mathrm{hr})$ で抑制された
血栓表面上で新たな血栓形成が増加する傾向に あった。

\section{B. \% 血栓面積（図 8 B) :}

$\%$ 血栓面積は \% 血管閉塞率の経時的変化 と同様の傾向を認め, t-PA 単独投与群に比し投 与開始後 1 2 時間においてアルガトロバン $(0.3 \mathrm{mg} / \mathrm{kg} ・ \mathrm{hr})$ で有意の減少を示したが, UFH 群では 2 時間後以降遅延する傾向を認め た.

\section{考案}

近年，本邦においても急性心筋梗塞に対する 血栓溶解剤として t-PA が臨床応用されている が，併用される抗凝固薬についての検討成績は 乏し( ${ }^{23)}$. 今回著者らは hamster の cheek pouch を用い, 蛍光色素-光反応により微小血管 内に固着性壁在血栓を作製し, t-PA による血栓 溶解過程に及ぼすアルガトロバンと UFH の影 響について比較検討した。本法では，高田及び 

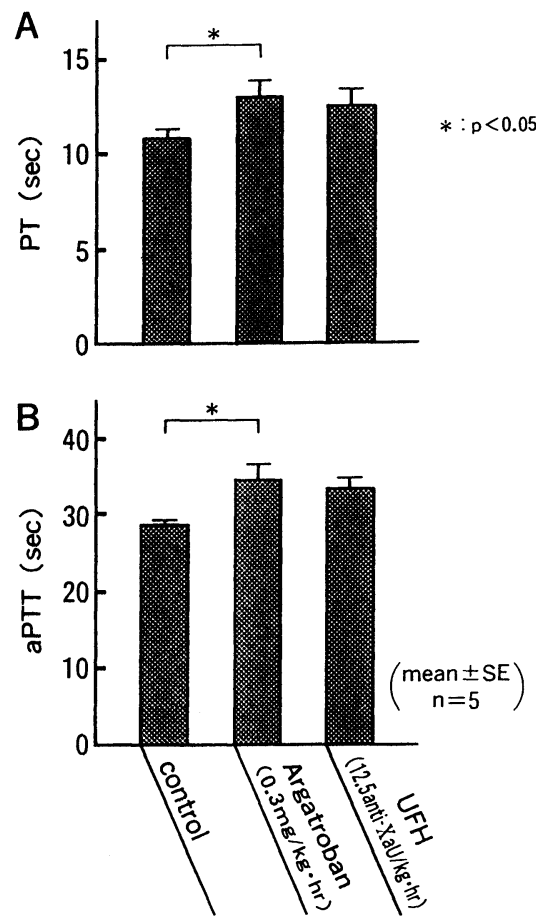

Fig. 7 Effects of argatroban and UFH on PT and aPTT. Argatroban significantly prolonged PT (A) and aPTT (B) as compared with control, but UFH did not. Values were expressed as mean $\pm \mathrm{SE}$.

米田ら ${ }^{4) 5)}$ が報告しているように一定の条件下 で一定面積の血小板血栓が再現制よく形成さ れ, 血栓溶解効果を比較するのに適しているも のと考えられる。

抗凝固薬が血栓溶解を促進する機序として は，血栓溶解に伴い血栓表面上に出現するト口 ンビンによる新しい血栓形成を阻害することが 考えられている，従来, 線溶療法における抗凝 固剤としてへパリンが広く用いられているが本 実験においてへパリンは t-PA による血栓溶解 を遅延させた。これはへパリンがトロンビンに 対して液相では効果的な阻害剤であるがフィブ リンに結合したトロンビンに対しては阻害作用 が弱いという既報の実験結果と一致するもので あった ${ }^{677) 8}$. Weitz ら7)によると, 遊離トロンビ ンを抑制するには $0.1 \mathrm{U} / \mathrm{ml}$ の濃度のへパリン で十分であるがフィブリン塊に結合したトロン ビンを抑制するには $2 \mathrm{U} / \mathrm{m} l$ の濃度のヘパリン
が必要と報告される。ヘパリンの常用量である $0.2 \sim 0.4 \mathrm{U} / \mathrm{m} l$ の濃度では遊離トロンビンは 完全に抑制され得るがフィブリン塊に結合した トロンビンの 20 40\% しか抑制されないとさ れる. $5,000 \mathrm{U}$ のヘパリンをヒトに bolus で投 与すると $1 \mathrm{U} / \mathrm{m} l$ の濃度となるが, この濃度で はフィブリン塊に結合したトロンビンの $60 \%$ しか抑制し得ないとしている。ヘパリンが血栓 溶解を促進するという実験成績も散見される が，これらの実験に用いられたへパリンの投与 量はいずれも高濃度であり, PT, aPTT を著し く延長させている. Schneider ら aPTT を 5.3 倍に延長させる投与量ではへパ リンは r-scu-PA (recombinant single chain urokinase-type plasminogen activator)によ る血栓溶解を促進したが，2.5 倍に延長させる 投与量では血栓溶解を促進しなかったとしてい る. 今回筆者らの用いたへパリンの投与量は比 較的低濃度であり, t-PA による血栓溶解を促進 させなかったと考えられる。ヘパリンの t-PA による血栓溶解を遅延させる機序としては，血 栓の溶解によって血栓表面に露出したトロンビ ンに対してへパリン-AT III 複合体の分子量が 大きく作用しなかったこと㫜やへパリンがプラ スミノゲンの血栓への結合を妨げること孚が考 えられるが，他に AT III のへパリンによる消 費9)，トロンビンのへパリン結合部位のフィブ リン結合による隠蔽7), 活性化血小板より放出 された血小板第 4 因子，トロンボスポンジンに よるへパリンの作用の中和 ${ }^{9)}$ ，フィブリンモ， マーによるへパリンの作用の阻害 ${ }^{10)}$ などが挙 げられる。一方，アルガトロバンはへパリンに 比し PT 及び aPTT において有意な延長を認 めない濃度において, t-PA による血栓溶解を有 意に促進させた。この機序としてアルガトロバ ンは分子量が小さく, 血栓溶解過程において出 現するフィブリン上のトロンビンに対して効果 的に阻害作用を発揮し，血栓表面での新たな血 栓形成を抑制させ，血栓溶解が効率的に進行す るためと考えられた ${ }^{6) 1213) 14)}$. 実際, t-PA 単独投 与時に血栓溶解過程を観察すると血栓溶解の進 行と平行して血栓が形成され, 血流は途絶と再 疎通を繰り返すが，アルガトロバンを併用した 

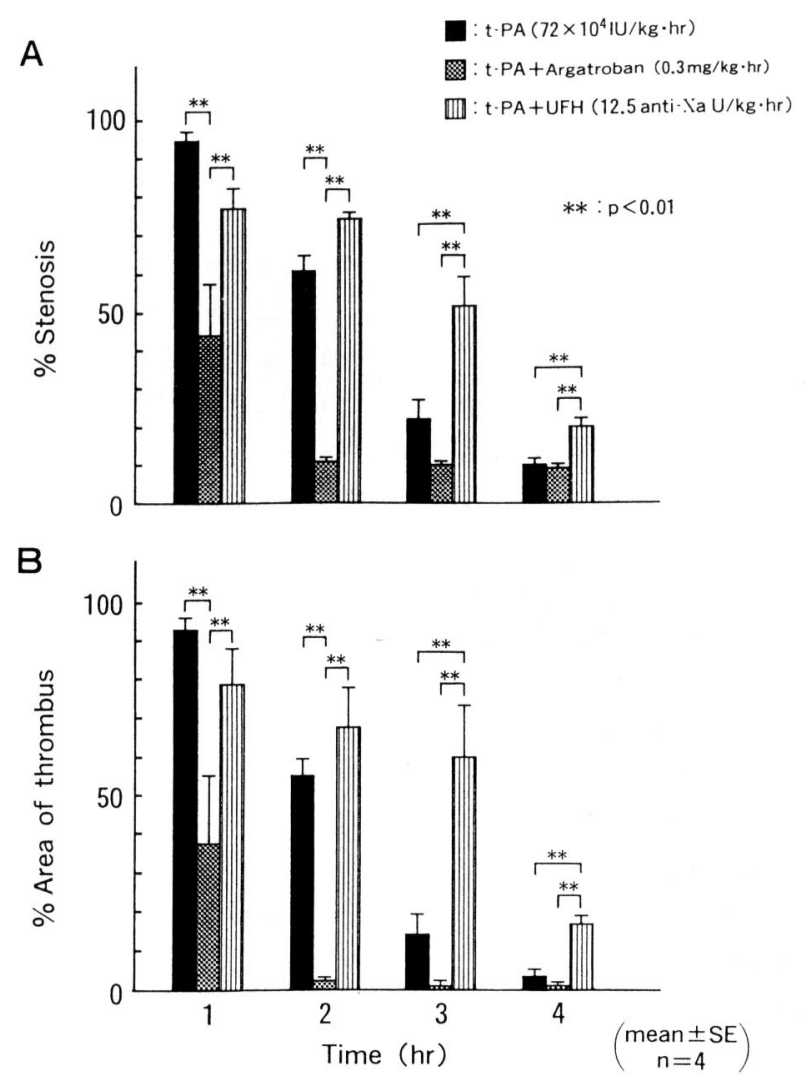

Fig. 8 Effects of argatroban and UFH on t-PA induced thrombolysis. Argatroban accelerated the decrease of percent stenosis (A) and that of area of the thrombus (B), but UFH delayed them. Values were expressed as mean $\pm \mathrm{SE}$.

場合には，投与量依存性にこの現象が著明に減 少するのが観察された。またアルガトロバンは トロンビンによるXIII 因子の活性化を抑制す るため,フィブリン中の $\alpha_{2}$-プラスミン・インヒ ビターとフィブリンとの結合が抑制されること が報告され，血栓表面に生成された新たな血栓 が溶解作用を受けやすいとも考えられる ${ }^{14115)}$. 以上のことより，アルガトロバンは固相上での 血栓形成を抑制させた結果，速やかな血管の再 疎通が得られ, t-PAによる血栓溶解を促進させ たものと推測される.

凝血学的検討において，アルガトロバンによ る $\mathrm{PT}, \mathrm{aPTT}$ 及び出血時間の有意の延長は 0.1 あるいは $0.2 \mathrm{mg} / \mathrm{kg} ・ \mathrm{hr}$ 投与下において認 められないが， $0.3 \mathrm{mg} / \mathrm{kg} \cdot \mathrm{hr}$ 投与下ではコン トロール群に比し有意に延長した。血栓溶解促
進効果については $0.1 \mathrm{mg} / \mathrm{kg} \cdot \mathrm{hr}$ 投与群, 0.2 $\mathrm{mg} / \mathrm{kg} \cdot \mathrm{hr}$ 投与群及び $0.3 \mathrm{mg} / \mathrm{kg} \cdot \mathrm{hr}$ 投与群 のいづれにおいても t-PA 単独投与群に比し有 意な血栓溶解の促進が認められたが，これらの 3 群間に有意差はなかった.したがって，投与量 の増加による出血の危険を避ける上からはアル ガトロバン $0.1 \sim 0.2 \mathrm{mg} / \mathrm{kg} ・ \mathrm{hr}$ 投与が本血栓 モデルにおいては適当と考えられた。

\section{結語}

トロンビンの特糞的阻害薬であるアルガトロ バンは従来のへパリンに比し,t-PAによる血栓 溶解を促進させ，血栓溶解療法に扔ける併用抗 凝固薬として有用と推察された。

なお, 本論文の要旨は第 15 回日本血栓止血学 会にて発表した。 


\section{文献}

1) Shanberge J.N., Tuji H. and Longe T.Q. : Production of thrombi on intact endothelium by use of antiheparin agents in vivo. J. Lab. Clin. Med. 116 : 831 839, 1990.

2) Gold H.K., Yasuda T., Jang I.K., Guerrero J.L., Fallon J.T., Leinbach R.C., and Collen D. : Animal model for arterial thrombolysis and prevention of reocclusion. Circulation 83 (Suppl. IV) : 26〜40, 1991.

3) Jang I.K., Gold H.K., Ziskind A.A., Fallonet J.T., Holt R.E., Leinbch R.C., May J.W. and Cllen D. : Differential sensitivity of erythrocyte-rich and platelet-rich arterial thrombi to lysis with recombinant tissue-type plasminogen activator. Circulation $79: 920 \sim 928,1989$.

4) 高田 治, 辻 肇, 米田 充, 渡辺雅彦, 亀田 充, 山本克巳, 加藤一睛, 小林恭一郎, 澤田昌平, 中川雅 夫 : 微小血管内血栓モデルによる低分子へパリンの 抗血栓作用の検討. 腎藏 $14: 30 \sim 34,1991$.

5）米田 充, 辻 肇, 高田 治, 中川 克, 山田恵三, 山田結佳, 増田治史, 中川雅夫 : t-PA による血栓溶 解過程におけるへパリン併用の効果に関する検討. 腎藏 $15:$ 15〜18, 1992.

6) Mirshai M., Soria J., Soria C., Faivre R., Lu H., Courtney M., Roitsh C., Tripier D., and Caen J. P. : Evaluation of the inhibition by heparin and hirudin of coagulation activation during t-PA induced thrombolysis. Blood $74: 1025 \sim 1030$, 1989.

7) Weitz J.I., Hudoba M., Massel D., Marganore J. and Hirsh J. : Clot bound thrombin is protected from inhibition by heparin-Antithrombin III but is susceptible to inactivation by Antithrombin III -independent inhibitors. J. Clin. Invest. $86: 385$ 〜391, 1990.

8) Görög P., Ridler C.D. and Kovacs I.B. : Heparin inhibits spontaneous thrombolysis and throm- bolytic effect of both streptokinase and tissuetype plasminogen activator. An in vitro study of the dislodgement of platelet-rich thrombi formed from native blood. J. Int. Med. 227:125 132, 1990.

9) Schneider J. : Heparin and the thrombin inhibitor argatroban enhance fibrinolysis by infused or bolusinjected saruplase $(r-s c u-P A)$ in rabit femoral artery thrombosis. Thromb. Res. $64: 677$ $\sim 689,1991$.

10) Hogg P.J., and Jackson C.M. : Fibrin monomer protects thrombin from inactivation by heparinantithrombin: implication for heparin efficacy. Proc. Natl. Acad. Sci. 86 : 3619 3626, 1989.

11) Tsuji H., Yoneda M., Takada O., Nakagawa K., Masuda H., Yamada K., Yamada Y., Yamagami M., Sawada S. and Nakagawa M., The effect of anticoagulants on thrombolysis in an experimental model using hamster microvasculature. JAMA SEA 8(Suppl.) : 55 58, 1992.

12) Jang I.K., Gold H.K., Leinbach R.C., Fallon J.T., and Collen D. : In vivo thrombin inhibition engances and sustains arterial recanalization with recombinant tissue-type plasminogen activator. Circulation Res. 67 : 1552 1561, 1990.

13) Fitzgerald D.J., and Fitzgerald G.A. : Role of thrombin and thromboxane $\mathrm{A} 2$ in reocclusin following coronary thrombolysis with tissue type plasminogen activator. Proc. Natl. Acad. Sci. USA. 86 : 7585 7589, 1989.

14) Tamao Y., Yamamoto T., Kikumoto R., Hara H., Itoh J., Hirata T., Mineo K. and Okamoto S. : Effect of a selective thrombin inhibitor MCI9038 on fibrinolysis in vitro and in vivo. Thromb. Haemostas. 56 : 28〜 34, 1986.

15) Sakata Y., Aoki N. : Crosslinking of $\alpha_{2}$-plasmin inhibitor to fibrin by fibrin-stabilizing factor. J. Clin. Invest. 65290 297, 1980. 